\title{
FILANTROPI ISLAM DAN PEMBERDAYAAN EKONOMI
}

\author{
Udin Saripudin \\ Ekonomi Syari'ah STAI Bhakti Persada Bandung \\ udin_saripudin27@yahoo.co.id
}

\begin{abstract}
Poverty is an interesting theme discussed especially among social scientists. Before getting to know scientific studies on the issue of poverty, the community has been running a tradition to respond to the problems of poverty in the form of giving. The "give" in its various forms is not limited in the form of money or goods but also the work or efforts to ease the burden on the poor and improve their well-being referred to as philanthropy. With descriptive methods this paper seeks explain and explore how the link between philanthropy Islam (zakat, donation and charity) and poverty reduction that occurs in a country, so the role of zakat, donation and charity as an instrument of distributive justice can be felt by the poor.
\end{abstract}

Keywords: Islamic Philanthropy, Economic Empowerment

- Pendahuluan

- Filantropi Dalam Tradisi Islam

Kata "filantropi" merupakan istilah baru dalam Islam, namun demikian belakangan ini sejumlah istilah Arab digunakan sebagai padanannya. Filantropi kadang-kadang disamakan dengan al-'ata' al-ijtima'i yang artinya pemberian sosial, al-takaful al-insani yang artinya solidaritas kemanusiaan, 'ata' khayri yang artinya pemberian untuk kebaikan, atau sadaqah yang artinya sedekah (Ibrahim, 2008: 11). Istilah sadaqah sudah dikenal dalam Islam, tetapi istilah filantropi Islam merupakan pengadopsian kata pada masa sekarang.

Kata filantropi berasal dari kata Yunani, yaitu dari kata philo yang artinya cinta dan anthrophos yang artinya manusia (Sulek, 2010: 386). Filantropi itu sendiri lebih dekat maknanya dengan charity, kata yang berasal dari Bahasa Latin (caritas) 


\section{Udin Saripudin}

yang artinya cinta tak bersyarat (unconditioned love). Namun, sebenarnya terdapat perbedaan antara kedua istilah tersebut, charity cenderung mengacu pada pemberian jangka pendek, sedangkan filantropi lebih bersifat jangka panjang (Anheier dan List, 2005: 196, Anderson, 2007: 26).

Makna filantropi di atas telah melahirkan beragam definisi. Filantropi diartikan sebagai tindakan sukarela personal yang didorong kecenderungan untuk menegakkan kemaslahatan umum (Friedman dan McGarvie, 2003: 37), atau perbuatan sukarela untuk kemaslahatan umum (Payton dan Moody, 2008: 6). Filantropi juga diartikan sebagai sumbangan baik materi maupun non materi untuk mendukung sebuah kegiatan yang bersifat sosial tanpa balas jasa bagi pemberinya (Anheier dan List, 2005: 196). Definisi di atas menunjukkan bahwa tujuan umum yang mendasari setiap definisi filantropi adalah cinta yang diwujudkan dalam bentuk solidaritas sesame manusia (Sulek, 2010: 395).

Praktik filantropi telah ada sebelum Islam seiring dengan berkembangnya wacana keadilan social (Rahardjo, 2003: 34). Filantropi juga bukan merupakan tradisi yang baru dikenal pada masa modern, sebab kepedulian seseorang terhadap sesame manusia juga ditemukan pada zaman kuno (Young, 2000: 149-172).

Agam Kristen juga menekankan pada pengikut awalnya untuk melaksanakan filantropi, demikian pula di kalangan Zoroastrianisme filantropi menjadi salah satu komitmen penting dalam kehidupan mereka. Filantropi tidak hanya ditemukan dalam tradisi keagamaan Timur Tenganh, melainkan juga di wilayah lain, seperti Hindu dan Budha di India, agama asli Afrika dan Amerika, agama-agama di Cina dan Jepang, serta bentuk keyakinan lainnya di berbagai belahan dunia.

Islam tampil bukan dalam ruang sejarah hampa, melainkan berhadapan dengan berbagai tradisi sebelumnya, demikian pula dengan tradisi filantropi dari agama sebelumya (Lapidus, 1995): 265). W. Haffening (1987: 1098) berpendapat bahwa tradisi filantropi dalam Islam mmerupakan warisan dari agama Yahudi dan Kristen, sedangkan A. G. Perikhanian (1986: 661) mengemukakan bahwa filantropi Islam banyak dipengaruhi oleh model filantropi Zoroastrian, keduanya 
memiliki kesamaan terutama dalam penekanan terhadap masalah wakaf.

Semangat filantropi dalam Islam dapat ditemukan dalam sejumlah ayat al-Quran dan hadits nabi yang menganjurkan umatnya agar berderma (Kaleem dan Ahmed, 2010: 416), dalam QS. Al-Baqarah ayat 215 disebutkan:

"Mereka akan bertanya kepadamu (Muhammad) tentang apa yang harus mereka infakkan. Katakanlah: 'Apapun kebaikan yang kamu infakkan kepada orang tua dan keluarga, anak yatim, orang miskin, dan orang asing, dan kebaikan apapun yang kamu lakukan, Allah pasti mengetahuinya'".

Ayat al-Qur'an tersebut diperkuat oleh salah satu hadits Nabi Saw. yang menyebutkan:

"Perbuatan baik itu menjadi penghalang bagi jalannya keburukan, sedekah sembunyi-sembunyi dapat memadamkan amarah Tuhan, silaturahim dapat memperpanjang umur, dan setiap kebaikan adalah sadaqah. Pemilik kebaikan di dunia adalah pemilik kebaikan di akhirat, dan pemilik keburukan di dunia adalah pemilik keburukan di akhirat, dan yang pertama masuk surga adalah pemilik kebaikan".

Ke dua dalil di atas menunjukkan bahwa prinsip umum filantripi Islam adalah "setiap kebaikan merupakan sedekah" (Sayyid Sabiq, 1982: 357). Semangat filantropi dalam Islam dapat dibuktikan dalam wujud pelaksanaan zakat, infak, sedekah, hadiah dan sebagainya.

\section{Bentuk-Bentuk Filantropi Dalam Islam}

Islam mengenal dua dimensi utama hubungan, yaitu hubungan manusia dengan Allah, dan hubungan manusia dengan manusia (Alhasbi dan Ghazali, 1994: 7-22). Tujuan dari kedua hubungan ini adalah keselarasan dan kemantapan hubungan dengan Allah SWT, dan sesama manusia termasuk dirinya sendiri dan lingkungan. Inilah aqidah atau keyakinan dan wasilah (jalan) untuk mencapai kesejahteraan baik di dunia maupun di akhirat (Ali, 1988: 29).

Kesejahteraan tersebut, tidak hanya diperoleh melalui hubungan dengan tuhan semata seperti; kewajiban shalat, puasa, dan haji, melainkan juga harus dibarengi dengan hubungan yang berdimensi sosial seperti kewajiban menngeluarkan zakat. Zakat termasuk infak dan sedekah 


\section{Udin Saripudin}

berfungsi untuk menjembatani dan mempererat hubungan sesama manusia terutama hubungan antara kelompok yang kuat dengan yang lemah (Bremer, 2004: 1-26).

\section{a. Zakat}

Zakat merupakan komponen utama kebijakan fiskal dalam ekonomi Islam. Dana zakat merupakan sumber pertama dan terpenting dari penerimaan negara, pada awal pemerintahan Islam (Shaikh, 2010: 1-18). Pada beberapa ayat Al-Quran zakat beberapa kali di sejajarkan dengan kewajiban shalat. Hal ini memang tidak diherankan karena zakat pun menjadi salah satu dari lima perkara yang harus dilakukan oleh seorang muslim, dimana Nabi Muhammad Saw., bersabda, "Islam dibangun di atas lima perkara: bersaksi bahwa tiada Ilah yang berhak disembah selain Allah dan Nabi Muhammad utusan Allah, menegakkan shalat, menunaikan zakat, melaksanakan haji, dan puasa Ramadhan." (HR. Bukhari dan Muslim)

Konsep zakat secara mendasar tidak mengalami perubahan yang signifikan dari waktu ke waktu. Hal yang membedakan hanyalah masalah operasional penghimpunan dan pemberdayaan dana zakat, karena konsep fikih zakat menyebutkan bahwa sistem zakat berusaha untuk mempertemukan pihak surplus muslim dengan pihak defisit muslim. Hal ini dengan harapan terjadi proyeksi pemerataan pendapatan antara surplus dan defisit muslim atau bahkan menjadikan kelompok yang defisit (mustahik) menjadi surplus (muzakki) (Nasution dan Wibisono, 2005: 48).

Perkembangan kajian dan pembahasan tentang zakat di Indonesia telah memasuki babak baru pasca disahkannya Undang-Undang nomor 38 tahun 1999 tentang Pengelolaan Zakat. Dalam Undang-Undang tersebut, zakat didefinisikan sebagai harta yang wajib disisihkan oleh seorang muslim atau badan yang dimiliki oleh orang muslim sesuai dengan ketentuan agama untuk diberikan kepada yang berhak menerimanya.

Zakat adalah bagian dari harta dengan persyaratan tertentu, yang Allah Swt. mewajibkan kepada pemiliknya, untuk diserahkan kepada yang berhak menerimanya, dengan persyaratan tertentu pula. Dengan pemahaman ini, zakat dapat 
dikategorikan sebagai ibadah maaliyah ijtima'iyyah, artinya ibadah di bidang harta yang memiliki kedudukan yang sangat penting dalam membangun masyarakat (Syafei, 2015: 155-164).

Menurut Chapra (1992: 1-4), zakat adalah instrumen pemerataan pendapatan dan kekayaan. Zakat merupakan tindakan bantu diri sosial yang mendapat dukungan kuat dari agama untuk menolong orang-orang miskin dan yang tidak beruntung yang tidak mampu berdiri sendiri sehingga menghapuskan penderitaan dan kemiskinan dari masyarakat muslim. Zakat bukanlah pengganti bagi program pembiayaan diri yang dibuat dalam masyarakat modern untuk menyediakan perlindungan jaminan sosial bagi pengangguran, kecelakaan, manula dan kesehatan, lewat pengurangan dari gaji pekerja dan kontribusi majikan.

Zakat bukanlah satu kegiatan yang semata-mata untuk tujuan duniawi, seperti distribusi pendapatan, stabilitas ekonomi, dan lainnya, tetapi juga mempunyai implikasi untuk kehidupan di akhirat. Hal inilah yang membedakan kebijakan fiskal dalam Islam dengan kebijakan fiskal dalam sistem ekonomi pasar (Suprayitno, Kader, dan Harun, 2013: 40-62). Hal ini berdasarkan Al-Qur'an surat At-Taubah ayat 103, yang artinya:

"Ambilah zakat dari sebagian harta mereka, dengan zakat itu kamu membersihkan dan menyucikan mereka dan berdoalah untuk mereka. Sesungguhnya doa kamu itu (menjadi) ketentraman jiwa bagi mereka. Dan Allah Maha Mendengar lagi Maha Mengetahui."

Zakat adalah ibadah dalam bidang harta yang mengandung hikmah dan manfaat yang demikian besar dan mulia, baik yang berkaitan dengan orang yang berzakat (muzakki), penerimanya (mustahik), harta yang dikeluarkan zakatnya, maupun bagi masyarakat keseluruhan (Qadir, 1998: 187).

Hikmah dan manfaat zakat tersebut diantaranya: a) sebagai perwujudan keimanan kepada Allah Swt., mensyukuri nikmat-Nya, menumbuhkan akhlak mulia dengan rasa kemanusiaan yang tinggi; b) membantu dan membina mustahik, terutama fakir miskin, ke arah kehidupan yang lebih baik dan lebih sejahtera, sehingga mereka dapat memenuhi kebutuhan hidupnya dengan layak, dapat beribadah kepada 


\section{Udin Saripudin}

Allah Swt.; c) sebagai pilar amal bersama antara orang-orang kaya yang berkecukupan hidupnya dan para mujahid, serta menjadi salah satu bentuk konkret dari jaminan sosial yang disyariatkan oleh ajaran Islam; d) sebagai salah satu sumber dana bagi pembangunan sarana maupun prasarana umat Islam; e) untuk memasyarakatkan etika bisnis yang benar, sebab zakat itu bukanlah membersihkan harta yang kotor, akan tetapi mengeluarkan bagian dari hak orang lain dari harta kita yang kita usahakan dengan baik dan benar; f) merupakan salah satu instrumen pemerataan pendapatan; dan g) mendorong umat Islam untuk mampu bekerja dan berusaha sehingga memiliki harta kekayaan untuk bekal beribadah (Hafidhuddin, 2002: 11).

\section{b. Infak}

Secara bahasa, kata infak berarti hal menafkahkan, membelanjakan, dan berarti pula mengeluarkan sesuatu (harta) untuk kepentingan sesuatu. Sedang kan menurut terminologi syariat, infak berarti mengeluarkan sebagian harta untuk suatu kebaikan yang diperintahkan Allah SWT (Djuanda, dkk., 2006: 11). Atau infak adalah pengeluaran suka rela yang dilakukan seseorang, setiap kali kita memperoleh rizki, sebanyak yang ia kehendakinya sendiri. Infak berarti memberikan harta dengan tanpa konpensasi apapun (Bremer, 2004: 1-26).

Infak tidak mengenal nisab, sehingga infak dikeluarkan oleh setiap orang yang beriman yang berpenghasilan tinggi maupun rendah dan disaat lapang ataupun sempit. Zakat harus diberikan kepada mustahik tertentu, tapi dalam infak boleh diberikan kepada siapa saja, misalnya untuk kedua orang tua, istri, anak yatim, dan sebagainya (Fauzia, 2008: 60-88).

Islam telah menentukan tatacara berinfak yaitu membuat ketentuan-ketentuannya, dan tidak membiarkan pemilik harta bebas mengelolanya dan menafkahkan sekehendaknya. Wujud pelaksanaan infak seseorang bisa dengan cara mentransfer hartanya dengan tanpa kompensasi kepada orang lain, kepada diri sendiri, ataupun kepada orang yang nafkahnya menjadi kewajiban. Wujud infak, bila kegiatan dilaksanakan ketika masih hidup, seperti hibah, hadiah, sedekah, serta nafkah, bila dilaksanakan setelah meninggal seperti wasiat. 
Infak memiliki hikmah yang besar baik bagi pemberi dan penerimanya, hal ini menumbuhkan sikap mental dan kesadaran bagi orang yang melaksanakan infak serta merupakan pemenuhan kebutuhan bagi orang yang menerimanya (Budiman, 2003: 119-143). Islam telah menggariskan tentang kewajiban pemberian kelebihan harta seseorang, sebagaimana firman Allah:

“...dan mereka bertanya kepadamu tentang apa yang mereka nafkahkan. Katakanlah:'yang lebih dari keperluan'. Demikianlah Allah menerangkan ayat-ayatNya kepadamu supaya kamu berfikir." (Q.S. Al-Baqarah: 219).

Kata "Al-Afw" yang dipakai dalam ayat diatas berarti sisa kebutuhan setelah memenuhi kebutuhan seseorang. Artinya bagi mereka yang hidup berlebihan terdapat hak masyarakat yang wajib dikeluarkan. Sementara takaran pengeluaran infak tergantung pada situasi dan kondisi, terkadang hukumnya wajib dan bisa menjadi fardhu (seperti nafkah suami kepada istrinya), dan terkadang sunnah (seperti infak untuk kepentingan umum) (Ausaf, 1987: 14-38).

Terdapat dua kewajiban yang dibebankan kepada setiap orang mu'min terhadap fakir miskin. Pertama, memberi makan dan merawatnya jika ia sanggup. Kedua, menganjurkan orang lain untuk menyantuni orang miskin jika ia termasuk orang yang hidup pas-pasan, jika tidak mereka digolongkan kedalam orang pendusta agama sebagaiman firman Allah dalam Surat Al-Ma'un: 1-3.

Perintah wajib menginfakkan kelebihan harta tercantum setelah anjuran beriman kepada Allah. "(Yaitu) mereka yang beriman kepada yang gaib, yang mendirikan shalat, dan menafkahkan sebagian rizki yang Kami anugrahkan kepada mereka." (Q.S. AlBaqarah: 3). Menurut Yusuf Qardhawi, Al-Qur'an menetapkan infak berupa sebagian dari rizki Allah, maksudnya yang dinafkahkan itu hanya sebagian, sedangkan sebagian lagi ditabungkan dan dikembangkan untuk kegiatan produktif (Faizal, Ridhwan, dan Kalsom, 2013: 191-196).

Islam mengajarkan manusia untuk suka memberi berdasarkan kebajikan, kebaktian, dan keikhlasan, serta melalui cara-cara yang baik. Infak merupakan amalan yang mulia jika dilakukan denga ikhlas semata-mata karena Allah, maka akan mendapat pahala yang baik di akhirat kelak. 
"Perumpamaan (nafkah yang dikeluarkan oleh) orang-orang yang menafkahkannya dijalan Allah, adalah serupa dengan sebutir benih yang menumbuhkan tujuh butir, pada tiap-tiap butir seratus biji. Allah Melipatgandakan (ganjaran) bagi siapa yang Dia kehendaki. Dan Allah Maha Luas (karunianya) lagi Maha Mengetahui." (Q.S. Al-Baqarah: 261).

\section{c. Sedekah}

Kata sedekah berasal dari bahasa arab yaitu shadaqa, artinya benar, menurut terminologi syariah, pengertian sedekah sama dengan pengertian infak, termasuk juga hukum dan ketentuannya, penekanan infak berkaitan dengan materi, sedangkan sedekah memiliki arti lebih luas menyangkut hal yang bersifat non-materi (Kato, 2014: 90-105). Sedekah juga diartikan sebagai pemberian seseorang secara ikhlas, kepada yang berhak menerimanya yang diiringi oleh pemberian pahala dari Allah (Makhrus dan Utami, 2015: 175-184).

Islam memperbolehkan adanya kepemilikan pribadi, sehingga secara fitrah terdapat individu-individu yang berinisiatif untuk memperoleh kekayaan sebanyak banyaknya. Karena Al-Qur'an mendorong semua orang untuk berusaha mencari kekayaan untuk dirinya sendiri. Akan tetapi perlu untuk diakui adanya seseorang lebih kaya dari yang lainnya. Allah berfirman:

"Dan Allah Melebihkan sebagian kamu dari sebagian yang lain dalam hal rizki, ..." (Q.S. An-Nahl: 71).

Islam tidaklah menetapkan seberapa besar harta yang disedekahkan, namun mendidik manusia untuk mengeluarkan harta dalam bersedekah dan berinfak baik dikala susah ataupun senang, siang ataupun malam, dan secara sembunyisembunyi ataupun terang-terangan sesuai dengan kemampuan. Jika manusia enggan berinfak atau bersedekah, maka sama halnya dengan menjatuhkan diri pada kebinasaan.

"Dan belanjakanlah (harta bendamu) di jalan Allah, dan janganlah kamu menjatuhkan dirimu sendiri kedalam kebinasaan, dan berbuat baiklah, karena sesungguhnya Allah Menyukai orang-orang yang berbuat baik." (Q.S. AlBaqarah:195). 
Sedekah tidak ditentukan jumlah dan sasaran penggunaannya, yaitu semua kebaikan yang diperintahkan oleh Allah. Wujud sedekah tidaklah terbatas hanya pada halhal yang material saja, akan tetapi dalam sedekah tercakup halhal yang bersifat non-material, yaitu memberi nasihat, melaksanakan amar ma'ruf nahyi munkar, mendamaikan yang berseteru, membaca tasbih, tahmid, tahlil, dan sebagainya (Retsikas, 2014: 337-357).

\section{Zakat, Infak, Sedekah Dan Pemberdayaan Ekonomi Masyarakat}

\section{a. Potensi Zakat, Infak, dan Sedekah di Indonesia}

Besarnya potensi zakat nasional telah banyak diungkap oleh berbagai penelitian. Riset yang dilakukan Pusat Bahasa dan Budaya UIN Syarif Hidayatullah Jakarta pada 2005, menyimpulkan, potensi zakat mencapai angka Rp19,3 triliun (Bamualim dan Bakar, 2005). Monzer Kahf menyatakan, potensi zakat nasional bisa mencapai dua persen dari total PDB (Kahf, 1989: 1-22), sehingga potensi zakat tidak kurang dari Rp100 triliun (Jaelani, 2016: 9-15). Pusat Ekonomi dan Bisnis Syariah Fakultas Ekonomi Universitas Indonesia (PEBS FEUI) (2011), mengestimasi potensi dana zakat Indonesia untuk kurun waktu 2005-2011 seperti ditunjukkan dalam Tabel 1.

Tabel 1. Potensi Zakat Indonesia (Milyar, Rp.)

\begin{tabular}{llllllll}
\hline & 2005 & 2006 & 2007 & 2008 & 2009 & 2010 & 2011 \\
\hline PDB Nominal & 2.774 .281 & 3.339 .217 & 3.950 .893 & 4.951 .357 & 5.613 .442 & 6.253 .790 & 7.006 .727 \\
Potensi Zakat: & & & & & & & \\
$1,0 \%$ dari PDB & 27.743 & 33.392 & 39.509 & 49.514 & 56.134 & 62.538 & 70.067 \\
$1,7 \%$ dari PDB & 47.163 & 56.767 & 67.165 & 84.173 & 95.429 & 106.314 & 119.114 \\
$2,0 \%$ dari PDB & 55.486 & 66.784 & 79.018 & 99.027 & 112.269 & 125.076 & 140.135 \\
\hline
\end{tabular}

Setelah kedua penelitian ini, BAZNAS bekerja sama dengan Fakultas Ekonomi dan Manajemen (FEM) Institut Pertanian Bogor (IPB) pada awal 2011 melakukan penelitian potensi zakat dengan menggunakan data yang diolah dari Survei Sosial Ekonomi Nasional (SUSENAS) Badan Pusat Statistik (BPS) dan institusi lain yang relevan seperti Bank Indonesia (BI). Dalam risetnya, BAZNAS dan FEM IPB mengklasifikasi potensi zakat secara nasional dalam tiga kelompok. Yaitu, potensi zakat rumah tangga, potensi zakat 


\section{Udin Saripudin}

industri menengah dan besar serta Badan Usaha Milik Negara (BUMN), dan potensi zakat tabungan.

Khusus dalam hal zakat rumah tangga, standar nishab yang dipakai adalah nishab zakat pertanian sebesar $524 \mathrm{~kg}$ dan kadar zakatnya $2,5 \%$. Sedangkan potensi zakat in dustri dan BUMN dihitung ber dasar kan keuntungan atau laba dari perusahaan yang bis nis intinya sejalan dengan aturan syariah. Dari penelitian ini diketahui, potensi zakat rumah tangga secara nasional mencapai Rp82,7 triliun. Angka ini equivalen dengan 1,3 persen dari total PDB. Sedangkan potensi zakat industri mencapai angka Rp114,89 triliun, yang Rp22 triliunnya berasal dari indutri pengolahan. Dan zakat BUMN mencapai Rp 2,4 triliun.

Sementara itu, potensi zakat tabungan mencapai angka Rp17 triliun. Angka ini diperoleh dari penjumlahan potensi berbagai aspek, antara lain potensi tabungan di bank syariah, tabungan BUMN atau bank pemerintah campuran, badan usaha bukan keuangan milik negara, bank persero, dan bank pemerintah daerah. Tabungan yang dihitung adalah yang nilainya berada di atas nishab 85 gram emas.

Angka ini akan terus meningkat seiring dengan meningkatnya jumlah PDB, seperti yang dikatakan pengurus Forum Zakat Indonesia, Sri Adi Bramasetia. Menurut dia, jika dikelola serius, potensi zakat itu dengan jumlah muslim terbesar di dunia, potensinya bisa mencapai Rp. 300 triliun. Bahkan, kata Menko Hatta Rajasa, bila infak, sedekah dan wakaf juga tergarap dengan baik potensinya akan mencapai empat kali lipat atau Rp868 triliun.

Dari riset ini juga diketahui potensi zakat rumah tangga provinsi. Jawa Barat tercatat sebagai provinsi dengan potensi zakat terbesar, yaitu sebesar Rp17,67 triliun, disusul Jawa Tengah dan Jawa timur yang memiliki potensi zakat masingmasing sebesar Rp15,49 triliun dan Rp13,28 triliun. Adapun provinsi yang memiliki potensi zakat rumah tangga terendah adalah Bali, Papua dan Papua Barat, yang masingmasing mencapai angka Rp126,25 miliar, Rp117,44 miliar, dan Rp111,68 miliar.

Selain meneliti potensi zakat, BAZNAS dan IPB juga meneliti faktor yang memengaruhi pembayaran zakat dengan mewawancarai 345 orang res ponden (muzakki dan munfik) di 
Palembang, Brebes, Kota Bogor dan Kabupaten Bogor. Hasilnya, kesanggupan seseorang membayar zakat ditentukan oleh tingginya tingkat pendidikan, jenis pekerjaan, dan tingkat pendapatan. Makin tinggi pendidikan dan pendapatan, makin tinggi pula kesadaran membayar zakat. Sebagian besar responden berzakat per tahun, kecuali petani yang disesuaikan dengan waktu panen (Mubarok dan Fanani, 2014: 7-16).

Dalam hal tempat pembayaran zakat, sebagian besar (72,8\%) membayar di lembaga amil zakat informal (lembaga yang tidak berbadan hukum, tapi fungsinya sama seperti lembaga amil formal). Sisanya (27,2\%) membayar ke lembaga amil formal berbadan hukum (BAZ dan LAZ). Alasan utama seseorang membayar zakat di lembaga amil informal ada lah kemudahan, lingkungan, dan kepuasan. Sedangkan alasan seseorang membayar zakat di lembaga formal adalah transparansi, akses, kemudahan, lingkungan dan kepuasan.

Mengapa sebagian besar lebih memilih lembaga amil zakat informal? Karena, yang formal terbatas jumlahnya dan jaraknya jauh, bahkan lokasinya tidak diketahui muzakki serta kurang memberikan sosialisasi. Maka, yang formal perlu membuka cabang di daerah yang potensinya besar bekerja sama dengan DKM setempat. Selain itu, perlu disediakan layanan jemput zakat atau faslitas pembayaran on line. Dalam hal berinfak, menurut riset ini, faktor yang memengaruhinya adalah pendidikan, jenis pekerjaan, pendapatan dan pengeluaran.

\section{b. Dampak Zakat, Infak, dan Sedekah terhadap Perekonomian}

Zakat merupakan instrument publik yang mempengaruhi sisi demand ekonomi (Zaim, 1989: 101-120). Secara teoritis, pendistribusian zakat akan mengakibatkan naiknya daya beli masyarakat mustahik yang pada akhirnya akan meningkatkan kurva permintaan melalui agregat demand (Sakti, 2007: 183-184).

Akan tetapi, secara jangka pendek akan meningkat harga. Namun, peningkatan harga itu otomatis akan meningkatan revenue produsen. Dan jika diasumsikan kenaikan harga ini diketahui semua pelaku pasar, dengan demikian akan mengundang pelaku pasar baru. Implikasinya 
harga akan terkoreksi. Turunnya harga ini tidak serta-merta akan menurunkan kuantitas produksi keseimbangan. Akan tetapi tetap meningkat. Inilah kemudian yang menunjukkan bahwa zakat mendorong pertumbuhan ekonomi. Lebih lengkap ditunjukkan oleh Gambar 1.

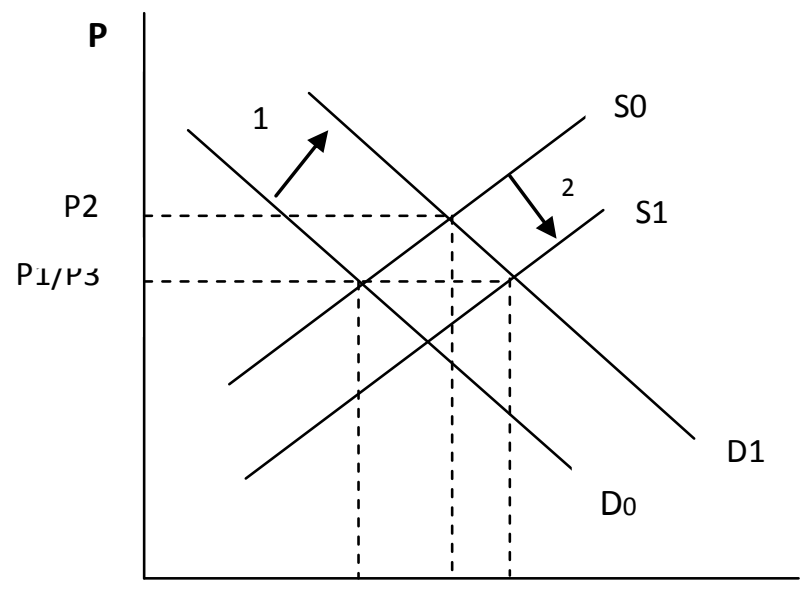

Gambar 1. Peßan Zakat teqhadaf3 Pefék konomian Q

Dari penjelasan di atas terlihat bahwa zakat berpotensi sebagai pendorong laju pertumbuhan ekonomi. Akan tetapi, tentunya potensi itu harus disertai dengan pengumpulan dana zakat yang optimal (Md. Nor, Razak, dan Noor, 2002: 69-80).

\section{c. Peran Zakat, Infak, dan Sedekah dalam Pengentasan Kemiskinan}

Muhammad adalah seorang pemimpin politik serta nabi. Sebagai seorang kepala Negara serta nabi, beliau mampu meletakkan dasar-dasar kepemimpinan yang adil serta mampu mewujudkan masyarakat madani. Islam sangat konsen dengan masalah-masalah kemiskinan serta konsep pembangunan modern. Masalah kemiskinan merupakan masalah yang telah dihadapi oleh umat manusia sepanjang sejarah peradaban manusia itu sendiri. Qardhawi meneliti posisi orang miskin sebelum Islam di peradaban kuno seperti Mesir dan Babel, kemiskinan yang mereka alami merupakan dampak dari 
mereka tidak memiliki akses lahan dan kegiatan produktif. Dalam memenuhi kebutuhan dasar, mereka menjual diri sebagai budak untuk orang kaya. Kemiskinan modern juga sebagian besar masih merupakan fungsi dari kurangnya akses modal produktif. Islam langsung merespon masalah ini dengan menekankan pentingnya keadilan sosial, jaminan sosial, dan solidaritas sosial seperti yang dijelaskan dalam al-Quran dan hadits (Qardhawi, 2009: 3-4).

Pentingnya kesetaraan dalam Islam terlihat jelas dalam redistribusi sumber daya melalui badan atau lembaga amal Islam seperti zakat, wakaf dan sedekah. Leaman menulis berjuang untuk orang miskin dianggap sebagai berjuang untuk jalan Allah dan setara dengan puasa dan doa (Leaman, 2006: 411-414). Kewajiban membayar zakat di al-Quran dinyatakan tiga puluh kali dan sebagian besar dari mereka terkait dengan kewajiban salat dalam ayat yang sama. Oleh karena itu, kita dapat mencatat bahwa Islam sangat konsen dengan masalah kemiskinan dan kesetaraan.

Islam memberi batasan kemiskinan sebagai ketidak mampuan individu dalam memenuhi lima persyaratan dasar dalam kehidupan yang terdiri dari agama, diri fisik, intelektual atau pengetahuan, keturunan dan kekayaan (Hassan, 2010: 261281). Ada dua istilah dalam al-Quran untuk mengungkapkan kondisi kemiskinan; faqr dan maskanah. Zakat hanya untuk fuqara (orang miskin) dan al masaakin (yang membutuhkan) ........ (QS 9:60). Fuqara adalah bentuk jamak dari faqr, menunjukkan kondisi bagi mereka yang tidak mampu mencukupi kebutuhan dasar mereka sendiri, sementara alMasaakin adalah jamak untuk maskanah yang artinya orangorang yang miskin dan sangat miskin. Meskipun, ulama Islam telah lama diperdebatkan kelompok mana yang paling membutuhkan dalam hidup mereka, Al-Qur'an menyatakan bahwa keduanya memenuhi syarat untuk menjadi penerima amal Islam. Amal Islam menjamin orang-orang miskin untuk memperoleh kebutuhan hidup yang cukup dengan transfer kekayaan dan distribusi pendapatan.

Amal Islam adalah instrumen utama yang memiliki peran sentral dalam pengentasan kemiskinan. Istilah luas amal disebut sedekah, ketika itu wajib, hal itu disebut sebagai zakat dan ketika manfaatnya diharapkan menjadi permanen, hal itu 
disebut shadaqa jariah atau wakaf (Obaidullah, 2008: 31-36). Zakat dan sedekah terlibat dalam pengentasan kemiskinan melalui distribusi pendapatan dan mentransfer kekayaan. Zakat juga digunakan untuk investasi jangka panjang untuk meningkatkan aspek non pendapatan dari orang miskin seperti kesehatan, pendidikan, sumber daya fisik, dan pekerjaan $(\mathrm{Md}$ Zuki, 2012: 173-178).

Bremer menggambarkan bagaimana skema zakat dalam pembangunan ekonomi, seperti yang dituangkan dalam Gambar 2.

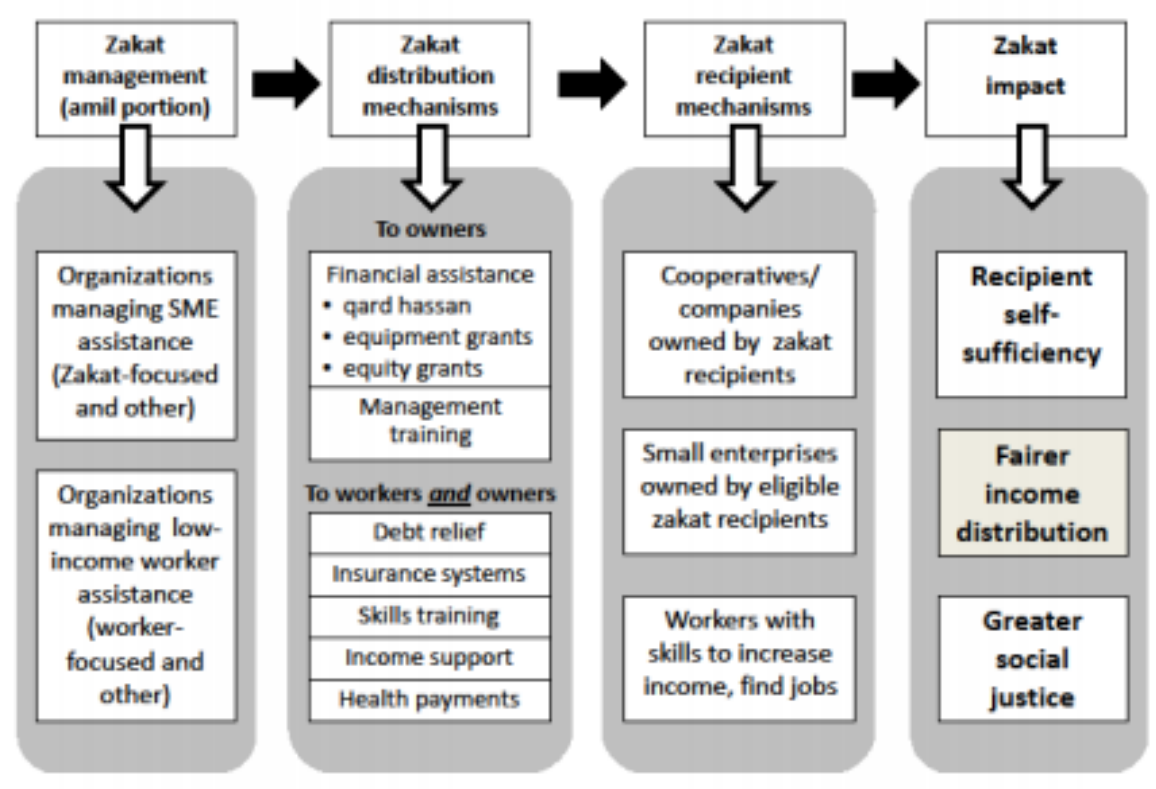

Gambar 2. Skema Zakat untuk Pembangunan Ekonomi (Ibrahim, 2008: 11)

\section{B. Simpulan}

Istilah filantropi merupakan hal baru dalam Islam, meskipun demikian praktik filantropi sebenarnya telah dipraktikan jauh sebelum istilah filantropi itu sendiri muncul. Berbagai bentuk filantropi diajarkan dalam Islam seperti; zakat, infak dan sedekah. Sebagai Negara dengan mayoritas penduduk beragama Islam, potensi zakat, infak dan sedekah di Indonesia sangatlah besar. Besarnya potensi zakat nasional telah banyak diungkap oleh berbagai penelitian. Riset yang 
dilakukan UIN Syarif Hidayatullah Jakarta pada 2005, menyimpulkan, potensi zakat mencapai angka Rp19,3 triliun. Monzer Kahf menyatakan, potensi zakat nasional bisa mencapai dua persen dari total PDB, sehingga potensi zakat tidak kurang dari Rp100 triliun.

Zakat, infak dan sedekah merupakan instrument keadilan distribusi dalam ekonomi Islam. Jika dikelola dengan baik dan professional, fotensi dana zakat yang besar ini akan berdampak signifikan terhadap perekonomian Indonesia, khususnya dalam upaya pengentasan kemiskinan di Indonesia. Distribusi zakat yang baik akan meningkatkan daya beli masyarakat dan menyebabkan pemerataan pendapatan, sehingga mampu meminimalisir kesenjangan yang terjadi di masyarakat. Zakat dan sedekah terlibat dalam pengentasan kemiskinan melalui distribusi pendapatan dan mentransfer kekayaan. Zakat juga digunakan untuk investasi jangka panjang untuk meningkatkan aspek non pendapatan dari orang miskin seperti kesehatan, pendidikan, sumber daya fisik, dan pekerjaan. 
Udin Saripudin

\section{Daftar Pustaka}

A. G. Perikhanian. 1986. "Iranian Society and Law", dalam Cambridge History of Iran, Cambridge: Cambridge University Press.

Aan Jaelani. 2016. "Zakah Management for Poverty Alleviation in Indonesia and Brunei Darussalam", MPRA Paper No. 69646 : Munich.

Abdulloh Mubarok dan Baihaqi Fanani, “Penghimpunan Dana Zakat Nasional (Potensi, Realisasi dan Peran Penting Organisasi Pengelola Zakat)", Permana Vol. 5 No. 2, (2014).

Abdurrachman Qadir, Zakat dalam Dimensi Mahdhah dan Sosial, (Jakarta: PT. Raja Grafindo Persada, 1998).

Ahmad Ausaf. 1987. Income Determination in an Islamic Economy, Jeddah, Saudi Arabia: Islamic Economics Research Centre.

Ahmad Kaleem and Saima Ahmed, "The Quran and Poverty Allevation: A Theoretical Model for Charity-Based Islamic Microfinance Institution", Nonprofit and Voluntary Sector Quarterly, 39:3, (2010).

Alhasbi S.O. and Ghazali A.H., 1994. Islamic Values and Management, (Kuala Lumpur: Institute of Islamic Understanding Malaysia.

Ali Sakti. 2007. Ekonomi Islam: Jawaban atas Kekacauan Ekonomi Modern, Jakarta: Paradigma dan Aqsa Publishing.

Amelia Fauzia, "Faith and the State: a History of Islamic Philanthropy in Indonesia", PhD thesis, Faculty of Arts, the University of Melbourne, (Melbourne: Asia Institute, 2008). 
Barbara Ibrahim. 2008. From Charity to Social Change; Trends in Arab Philanthropy, (Kairo: American University in Cairo Press.

Budi Budiman, "The Potential of Zis Fund as an Instrument in Islamic Economy: Its Theory and Management Implementation", Iqtisad Journal of Islamic Economics Vol. 4, No. 2, (2003).

Chaider Bamualim dan Irfan Abu Bakar, (ed). 2005. Revitalisasi Filantropi Islam: Studi Kasus Lembaga Zakat dan Wakaf di Indonesia, (Jakarta: CRCS UIN Jakarta.

Dennis R. Young, "Alternative Models of GovernmentNonprofit Sector Relations: Theoretical and International Perspectives", Nonprofit and Voluntary Sector Quarterly, vol. 29, no. 1, (Sage Publications, Inc., 2000).

Depag RI. 1989. Al-Qur'an dan Terjemahnya. Semarang: CV. Toha Putra.

Didin Hafidhuddin. 2002. Zakat dalam Perekonomian Modern, Jakarta: Gema Insani Press.

Eko Suprayitno, Radiah Abdul Kader, and Azhar Harun, "The Impact of Zakat on Aggregate Consumption in Malaysia", Journal of Islamic Economics, Banking and Finance, Vol. 9 No. 1, (IBTRA, 2013).

Gustian Djuanda, dkk., 2006. Zakat Pengurang Pajak Penghasilan, Jakarta: PT. Raja Grafindo Persada.

Helmut K. Anheier and Regina A. List. 2005. A. Dictionary of Civil Society, Philanthropy and the Non-Profit Sector, London-New York: Routledge.

Hisanori Kato, "Islamic Capitalism: The Muslim Approach to Economic Activities in Indonesia", Comparative Civilizations Review Number 71, (2014). 
Ira M. Lapidus. 1995. A History of Islamic Societies, Cambridge: Chambridge University Press.

Jennifer Bremer, "Islamic Philanthropy: Reviving Traditional Forms for Building Social Justice", CSID Fifth Annual Conference "Defining and Establishing Justice in Muslim Societies", (Washington DC, 2004).

Jennifer Bremer, "Zakat and Economic Justice: Emerging International Models and their Relevance for Egypt", Third Annual Conference on Arab Philanthropy and Civic Engagement June 4-6, (Department of Public Policy and Administration American University in Cairo, 2013).

Konstantinos Retsikas, "Reconceptualising Zakat in Indonesia", Indonesia and the Malay World, Volume 42, Issue 124, (2014).

Lawrence J. Friedman and Mark D. McGarvie, (2003). Charity, Philanthropy, and Civility in American History, (New York: Cambridge University Press.

Linsay Anderson, "Conspicuous Charity", MA Thesis (Texas: Texas A\&M University, 2007).

M. Dawam Rahardjo. 2003. “Filantropi Islam dan Keadilan Sosial: Mengurai Kebingungan Epistemologis", dalam Berderma untuk Semua: Wacana dan Praktik Filantropi Islam, ed. Idris Thaha, Jakarta: Teraju.

M. Kabir Hassan. 2010. "An Integrated Poverty Alleviation Model Combining Zakat, Awqaf and Micri-finance", 7th International Conference-The Tawhidy Epistemology, Zakat and Waqf Economy, Bangi Bangladesh.

Makhrus dan Restu Frida Utami, "Peran Filantropi Islam dalam Pemberdayaan Masyarakat di Kabupaten Banyumas", Prosiding Seminar Nasional Hasil-Hasil Penelitian dan Pengabdian LPPM Universitas Muhammadiyah Purwokerto, (2015). 
Filantropi Islam dan Pemberdayaan Ekonomi

Marty Sulek, "On the Classical Meaning of Philanthropia", Nonprofit and Voluntary Sector Quarterly, 39:3 (2010).

Mazrul Shahir Md Zuki, "Waqf and Its Role in Socio-Economic Development", International Journal of Islamic Finance, Vol. 4, Issue 2, (ISRA, 2012).

Monzer Kahf, "Zakat: Unresolved issues in the Contemporary Fiqh", Journal of Islamic Economics Vol. 2 No. 1, (1989).

Muhammad Daud Al. 1988. Sistem Ekonomi Islam; Zakat dan Wakaf, Jakarta: UI Press.

Muhammad Firdaus dan Irfan Syauqi Beik, "Potensi Zakat Rumah Tangga Nasional", Iqtishodia, Jurnal Ekonomi Islam Republika, (Kamis, 26 Mei 2011).

Muhammad Firdaus, Irfan Syauqi Beik, Tonny Irawan and Bambang Juanda. "Economic Estimation and Determinations of Zakat Potential in Indonesia". IRTI Working Paper Series, WP-1433-07, (IRTI/IDB, 2012).

Muhammad Obaidullah. 2008. Introduction to Islamic Microfinance, India: International Institute of Islamic Business and Finance.

Muhammad Umer Chapra. 1992. Islam and the Economic Challenge, Leicester, U.K. : The Islamic Foundation.

Mustafa Edwin Nasution dan Yusuf wibisono, "Zakat sebagai instrument pengentasan kemiskinan di era otonomi daerah", Proceedings of International Seminar on Islamic Economic as Solution, (Medan: IAEI, 2005).

Nor Ghani Md. Nor, Abd. Razak, and MohdAli Mohd Noor, "The Contribution of Zakat as an Income Creating Asset in SeJangor and Wilayah Persekutuan, Malaysia", Jumal Ekonomi Malaysia 36, (2002). 
Nur Barizah Abu Bakar and Abdul Rahim Abdul Rahman, "A Comparative Study of Zakah and Modern Taxation", J.KAU: Islamic Econ., Vol. 20, No. 1, (2007).

Oliver Leaman. 2006. "Money. in Oliver Leaman (ed.)", The Qur'an: An Encyclopaedia, London: Routledge.

P. R. M. Faizal, A. A. M. Ridhwan, and A. W. Kalsom, "The Entrepreneurs Characteristic from al-Quran and alHadis "International Journal of Trade, Economics and Finance, Vol. 4, No. 4, (2013).

PEBS-FEUI, Indonesia Shari'ah Economic Outlook (ISEO) 2011, (Jakarta: Lembaga Penerbit FEUI, 2011).

Robert L. Payton and Michael P. Moody, Understanding Philanthropy, (Bloomington and Indianapolis: Indiana University Press, 2008).

Sabahaddin Zaim, "Management of Zakah in Modern Muslim Society", Recent Interpretations on Economic Aspect of Zakah, (Jeddah: IRTI/IDB, 1989).

Salman Ahmed Shaikh, "Sources of Public Finance in an Islamic Economy", MPRA Paper No. 22998, (Munich: 2010).

Sayyid Sabiq, Figh al-Sunnah, (Beirut: Dar al-Fikr, 1982).

W. Haffening. 1987. "Waqf", dalam First Encyclopedia of Islam, Leiden: E.J. Brill.

Warren F. Ilchman, Stanley N. Katz dan Edward L. Queen II (eds), Filantropi di Berbagai Tradisi Dunia.

Yusuf Qardhawi, Figh Al Zakat. Translated by M. D. Kahf. Vol. 1, (Jeddah, Saudi Arabia: Scientific Publishing Centre, 2009).

Zakaria Syafei "Public Trust of Zakat Management in the Office of Religious Affairs, Cipocok Jaya, Serang, Banten, 
Filantropi Islam dan Pemberdayaan Ekonomi

Indonesia", Journal of Management and Sustainability; Vol. 5, No. 3, (Canadian Center of Science and Education, 2015). 